\title{
【奨励賞研究】
}

\section{光学マッピングによるー方向性興奮伝導領域検出を用いた 心内膜側リエントリ解析}

\author{
川島 圭太郎 \\ 東京電機大学大学院 理工学研究科 電子機械工学専攻
}

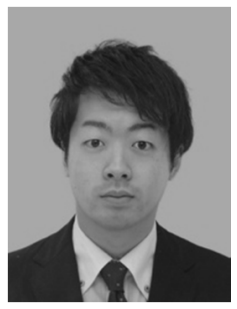

\section{1. 背景と目的}

心室頻拍や心室細動の成因は, 渦巻き状の興奮波が異常に旋回 し続ける『スパイラルリエントリ(以下, SWR)』である. 心臟の興奮様 式を可視化する光学マッピングを用いた研究では主に心外膜側に 生じた SWR が計測されてきた.一方, 芦原らによって心内膜側で起 きている SWR を可視化し経皮的カテーテル心筋焼灼術時を行う臨

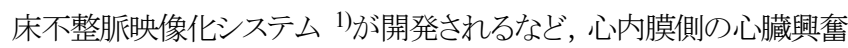
様式を理解することの重要性は高まっている. しか儿心内膜側の光 学マッピングはほとんど行われておうらず, 心臟興奮様式は未だ不明 な点が多い

また複雑な SWR の動態を理解する手段として旋回中心の検出が 行われてきた. 旋回中心検出法として位相分散解析があるが, あくま で心外膜表面における平面的な心筋上を伝播する興奮現象の解析 のために開発された手法である. 我々はウサギ心標本の心内膜側に 誘発した SWR に対して位相分散解析を行った結果, 乳頭筋や腱索 といった解剖学的構造物が入り乱れた心内膜側では自由壁と乳頭筋 の境界に偽陽性の位相分散值が頻出し, 旋回中心を示寸位相分散 值と区別がつかないことがわかった. また乳頭筋の領域を解剖画像 から手動で設定し，その領域を関心領域から除くと偽陽性位相分散 值は発生しないことを確認した. しかし経皮的カテーテル心筋焼昫 術時などでは解剖学的構造物の位置関係は不明であり, 自由壁と乳 頭筋の区別がつかないことが考えられる. またウサギ心標本におけ る乳頭筋を伝播する興奮波の特徴しして, SWR 発生中にも関わらず 一方向性を示寸ことがわかった. そこで本研究では興奮伝播ベク卜 ルの加算を利用して, 心室心内膜側における乳頭筋と自由壁を客観 的に分割する手法の考案を目的とする.

\section{2. 方法}

2 台の高速力メラを用いて心内膜における活動電位光学計測を行 い, 心室中隔自由壁および乳頭筋に伝播する興奮波を計測した (Fig.1). 等時相線図を導出し, 興奮波前面の継時変化から興奮伝播 ベタトルを算出した. 関心領域全画素におけるペーシング刺激時や 心室頻拍時などの興奮伝播様式を示寸興奮伝播ベクトルを累積し， 閾值を設定し乳頭筋領域の抽出を行った.

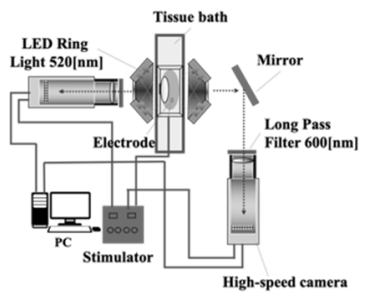

Fig.1 心室心内膜側光学マッピングシステム

\section{3. 結果}

提案手法である一方向興奮伝導領域検出を用いて, 左心室側, 右 心室側における乳頭筋領域を検出し，面積を算出した. また解剖写 真から手動で抽出した乳頭笳領域を算出し，提案手法による乳頭筋 面積検出結果と比較した(Table 1).

Table 1 検出した乳頭筋領域の面積

\begin{tabular}{|c|c|c|}
\hline & 提案手法による検出 & 目視による検出 \\
\hline $\begin{array}{c}\text { 左心室乳頭笳面 } \\
\text { 積[pixel] }\end{array}$ & $8.20 \times 10^{3}$ & $1.12 \times 10^{4}$ \\
\hline $\begin{array}{c}\text { 右心室乳頭筋面 } \\
\text { 積[pixel] }\end{array}$ & $2.37 \times 10^{3}$ & $6.86 \times 10^{3}$ \\
\hline
\end{tabular}

\section{4. 考察·結論}

提案手法から検出した左心室乳頭筋面積は目視による検出の 73.33[\%]を有していた. 一方, 提案手法から検出した右心室乳頭筋 面積は目視による検出の $34.51[\%]$ 有していた. 乳頭筋の大きさが 異なることや, 累積した不整脈時の興奮伝播様式が左室, 右室で異 なることが, 提案手法と目視による乳頭筋検出精度に差が生じた要 因と考える. 心室心内膜側における乳頭筋と自由壁を正確に分割す ることは困難であったが, 興奮伝播ベクトルの累積を利用し暗視下に おいても乳頭筋の位置を示唆可能であることが示された。

\section{参考文献}

1) K Sakata. Not all rotors, effective ablation targets for nonparoxysmal atrial fibrillation, are included in areas suggested by conventional indirect indicators of atrial fibrillation drivers. J Arrhythmia. p.177,p181. 2017. 